EESTI NSV TEADUSTE AKADEEMIA TOIMETISED. XVIII KÖIDE

KEEMIA * GEOLOOGIA, 1969, Nr. 2

ИЗВЕСТИЯ АҚАДЕМИИ НАУК ЭСТОНСКОИ ССР. ТОМ ХVII

ХиМИя - ГЕОЛОГИя. 1969, № 2

\title{
СТРАТИГРАФИЧЕСКОЕ РАСЧЛЕНЕНИЕ ПОЗДНЕЛЕДНИКОВЫХ ОТЛОЖЕНИЙ ЮЖНОЙ ЭСТОНИИ ПО ДАННЫМ СПОРОВО-ПЫЛЬЦЕВОГО АНАЛИЗА
}

На основе нсследования позднеледниковых отложений Южной Эстонии споровопыльцевым методом приводятся литологическая характеристика и стратиграфическое расчленение пяти разрезов: Выру, Реммески, Визузи, Сойтсъярв и Пяйдре. Рассматриваются общие закономерности изменения спорово-пыльцевого состава этих разрезов и их связь с убыванием ледника.

Для исследования по возможности выбирались разрезы наиболее глубоких частей бассейнов, характеризующие относительно полно позднеледниковые отложения и изменения их спорово-пыльцевого состава.

С целью получения критериев для стратиграфического расчленения позднеледниковых отложений был определен видовой состав древесных пород. Пыльца берез определялась до вида во всех образцах, а пыльца ольхи - в большинстве образцов. Из травянистых растений в некоторых образцах определялись виды семейства Chenopodiaceae, а из спор во всех образцах - споры семейства Lycopodiaceae.

При выделении фаз развития лесов использовались индексы Нильссона (Nilsson, 1935). Граниша между голоценом и плейстоценом проводилась между IX и X фазами развития лесов (Орвику, 1960; Orviku, 1961).

Местонахождение Выру находктся на северо-западном берегу озера Тамула, на окраине г. Выру. Озеро расположено в пределах широкой древней долины Выру и в районе изученного разреза сильно заросло тростником.

В основании толщи озерно-ледниковых и озерных отложений на морене, на глубине 12,50-13,00 м, залегает красновато-бурый песок с галькой, чередующийся через 15-20 cм со слоями глины мощностью $0,5 \mathrm{~cm}$. На глубине $12,00-12,50$ м выделяются хорошо сортированные крупнозернистые гравистые пески с тонкими прослоями глины. Эти надморенные отложения образовались в озерно-ледниковом бассейне близ края ледника в то время, когда привнос материала был значительным.

Над ними, на глубине 5,65-12,00 м, залегают ленточные глины, содержащие в нижней части местами прослойки мелкозернистого песка. В верхней части слоистость менее отчетливая, чем в нижней, и красновато-бурый цвет отложений приобретает сероватый оттенок. Песчанистые и алевритистые прослойки местами содержат листья и стебли зеленых мхов. Более обогащенные растительными остатками прослойки найдены на глубине $8,80-9,10$ и $7,40-7,70$ м. В этих отложениях рассеянно встречаются и некоторые листья карликовой березы (рис. $1 a$ ), а также полярных видов Salix. 

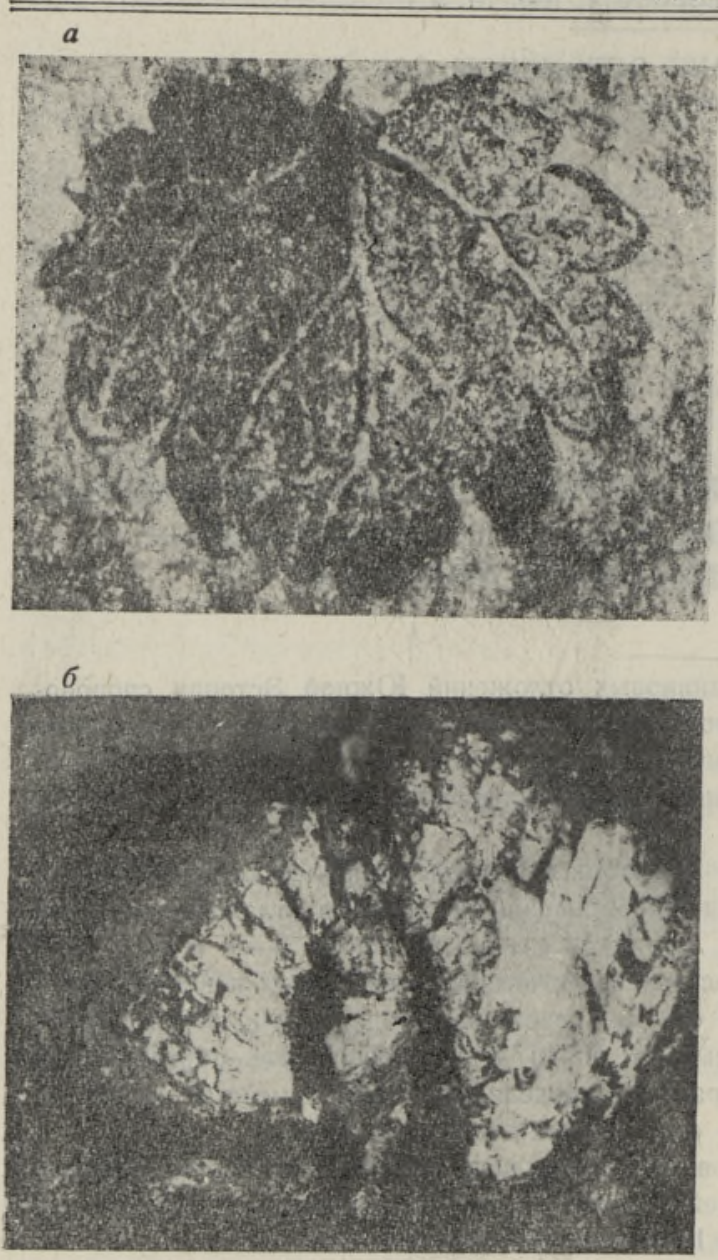

Pис. 1. $a-$ лист Betula nana из отложений XII зоны в разрезе Выру, $\times 12 ; \sigma$ - остатки раковины Anodonta sp. из отложений XI зоны в разрезе Выру, $\times 5$.

Выше по разрезу (3,005,65 м) залегают серые глины и алевриты с растительными остатками, черными прослойками и пятнами разложившейся органики. На глубине 5,20 м найдена раковина Anodonta sp. (рис. 1б). Вышележащие (2,653,00 м) зеленовато-серые алевриты с прослойками песка в верхней части содержат многочисленные остатки зеленых мхов.

Описанные отложения покрываются озерной известью и илистым осоковым торфом.

Судя по спорово-пылыцвой диаграмме разреза Выру, отложение озерно-ледниковых и озерных осадков началось, по-видимому, сразу после освобождения территории ото льда и продолжалось в голоцене. На диаграмме (рис. 2) представлены все фазы развития лесов позднеледниковья (XII, $\mathrm{XI}, \mathrm{X)}$ и нижние фазы голоцена. Верхняя часть голоценовых отложений не проанализирована.

Стратиграфия разреза Выру рассматривалась нами и раньше (Мянниль, Пиррус, 1963), но в то время нам удалось ознакомиться лишь с верхней частью позднеледниковых отложєний этого разреза.

Местонахождение Реммески находится в $20 \kappa м$ юго-восточнее г. Выру, на северо-восточном склоне Хааньяской возвышенности. В пределах небольшой замкнутой впадины между моренными холмами расположено болото - бывшее заросшее озеро.

На глубине 4,25-5,47 м на морене залегают серые алевриты с прослойками глины и в нижней части - песка. Отложения имеют ритмичную горизонтальную слоистость. По поверхностям слоев местами встречаются остатки зеленых мхов и тонкие ветви полярных кустарников. Слоистые отложения покрываются на глубине $3,34-4,25$ м светлосерым алевритом и темно-зеленым сапропелистым алевритом, содержащим растительные остатки. Выше, начиная с глубины 3,34 м, залегаютсапропель и низинный торф.

Спорово-пыльцевая диаграмма охватывает отложения всех фаз развития лесов позднеледниковья и пребореального периода (рис. 3).

Местонахождение Визузи расположено в северной части Саадъ- 


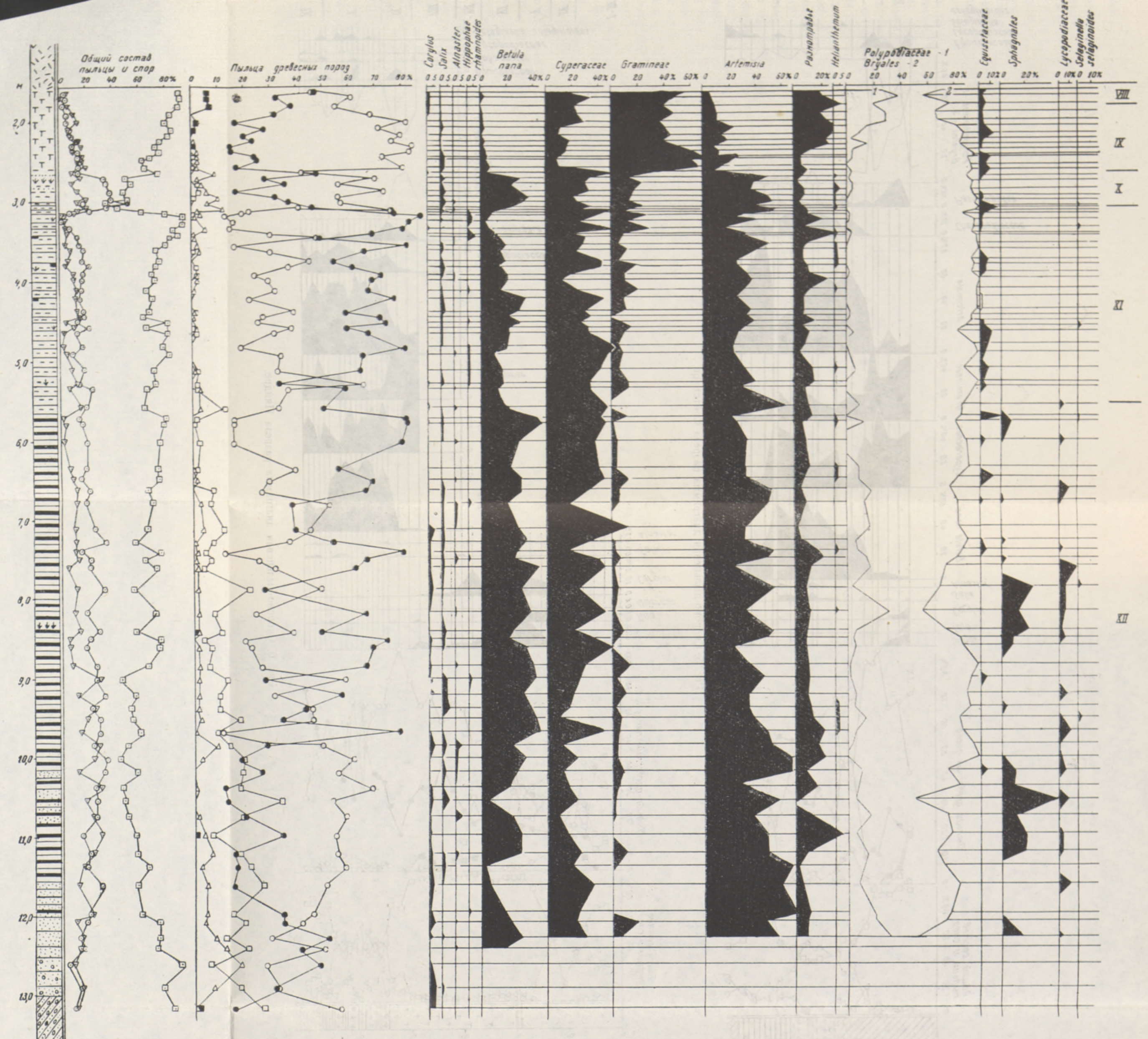


ярвского друмлинового поля. Скважина заложена в середине впадины заросшего междрумлинового озера.

На морене залегают глины и алеврнты коричневого и выше - сероватого цвета с ритмичной горизонтальной слоистостью. В нижней части отложения песчанистые. Выше, на глубине 4,90-5,50 м, залегают серые алевритистые глины с черными прослойками и редкими растительными остатками. На глубине 4,00-4,90 м вскрыты глинистые и алевритистые отложения, богатые остатками зеленых мхов. Описанные отложения покрыты озерной известью, сапропелем и торфом.

На спорово-пыльцевой диаграмме приведены все фазы развития лесов позднеледниковья и голоцена (рис. 4 ; таблица*).

Местонахождение С ойтсъя в расположено на болотной равнине между друмлинами, в 8 км юго-восточнее разреза Визузи. Скважина заложена вблизи северо-восточной части одноименного озера.

На морене, на глубине $5,30-6,30$ м, залегают коричневатые алевриты со слабо заметной горизонтальной слоистостью и алевритистые глины с примесью крупнозернистого песка. На глубине $4,40-5,30$. лежат зеленовато-серые алевриты с остатками зеленых мхов, покрытые сапропелем и низинным торфом.

Спорово-пыльцевая диаграмма охватывает нижнюю часть XII фазы развития лесов, Х фазу и голоценовые отложения (рис. 5). Это обус. ловлено, вероятно, расположением скважины в более мелководной части бывшего бассейна, где часть позднеледниковых отложений вовсе не отлагалась или была размыта.

Местонахождение Пяйдре находится в южной части Сакалаской возвышенности, юго-западнее г. Вильянди. Скважины заложены близ озера Пяйдре, расположенного в долине, соединяющей древние долины Раудна и Ыйзу-Римму.

Во всех скважинах в низах встречены плотные мелкозернистые серые пески и в береговой части бывшего бассейна - крупнозернистые пески, не пройденные буровыми скважинами. Над песками в изученном спорово-пыльцевым методом разрезе на глубине $5,50-6,00$ м залегают серые глины с примесью песка в нижней части. Выше, на глубине 4,45-5,50 м, находятся серые алевритистые глины с прослойками гипновых мхов, покрытые сапропелистой озерной известью, сапропелем и низинным торфом.

Спорово-пыльцевая диаграмма охватывает отложения X и, частично, XI фазы развития лесов и голоцена (рис. 6).

При выделении спорово-пыльцевых зон в указанных разрезах особое внимание уделялось 1) соотношению общего состава пыльцы и спор, особенно ходу кривых пыльцы травянистых растений и древесных пород, 2) ходу кривых пыльцы карликовой березы, 3) соотношению количеств пыльцы сосны, березы и других древесных пород. Кривые пыльцы отдельных травянистых и споровых растений не очень характерны, но и они часто бывают полезны при интерпретации спорово-пыльцевых диаграмм. Например, при определении границ между плейстоценом и голоценом одним из показателей является изменение состава травянистых растений.

Процентные соотношения пыльцы отдельных видов березы вычислены относительно суммы пыльцы берез. На диаграммы нанесена кривая карликовой березы, как наиболее характерного вида растительности позднеледниковья.

* Таблишы с данными спорово-пыльцевого анализа позднеледниковых отложений других месторождений здесь не приводятся по ссображениям технического характера. 
Прежде чем приступить к характеристике спорово-пыльцевого состава и его изменения в XII зоне, остановимся коротко на проблеме переотложения спор и пыльцы. В XII зоне по сравнению с более молодыми отложениями встречается значительно больше переотложенной пыльцы. На это указывают 1) плохая сохранность большого количества пыльцевых зерен, особенно древовидных берез и ольхи, 2) колебательный ход кривых отдельных древесных пород, карликовой березы и др., 3) присутствие пыльцы термофильных растений (Alnus glutinosa (L.) J. Gaertn., Carpinus betulus L., Corylus avellana L., некоторые широколиственные) совместно с пыльцой растений тундровой группы и перигляциальных ксерофитов, 4) сходство спорово-пыльцевых спектров в нижних слоях озерно-ледниковых отложений и в морене (см. рис. 2, 4, 5). Все эти признаки, вместе взятые, позволяют предполагать, что большая часть пыльцы, найденная в ленточных глинах и других озерно-ледниковых отложениях XII зоны, особенно в их нижней части, переотложена.

Состав пыльцы и спор показывает, что роль переотложенной пыльцы уменьшается вверх по разрезу, и уже в XI и X зонах содержание ее невелико, несмотря на то, что и здесь мы имеем дело не с органогенными отложениями. Это вполне понятно, так как вблизи ледника во время образования низов отложений озерно-ледниковых бассейнов доля переотложенной пыльцы была значительной вследствие сильного размыва и скудности окрестной растительности. В дальнейшем материал отлагался в более спокойных условиях и растительный покров стал более густым. Во время накопления отложений XI зоны во внутренних бассейнах Южной Әстонии размыв был слабым, а продукция пыльцы окрестной растительности - обильной. То же самое можно сказать и относительно Х зоны. По этой причине уменьшилось количество переотложенной пыльцы и спорово-пыльцевые спектры этих зон правдоподобнее отражают состав окрестной растительности, чем в более древних отложениях.

На спорово-пыльцевых диаграммах приведены все найденные зерна пыльцы и спор без выделения переотложенных. Вопросы переотложения пыльцы и спор тех или других растений затрагиваются при характеристике спорово-пыльцевого состава отложений отдельных стратиграфических зон.

По составу пыльцы древесных пород, сохранности пыльцы, участию явно переотложенной пыльцы и количеству пыльцы в образцах целесообразно условно разделить XII зону на две части. Для нижней части характерно преобладание пыльцы березы над пыльцой сосны и одновременно высокое и изменчивое содержание пыльцы ольхи (Реммески $10-30 \%$, Выру $6-34 \%$, Визузи $19-33 \%$, Сойтсъярв $36-49 \%$ ). Среди, пыльцы ольхи большая часть принадлежит Alnus glutinosa (L.) J. Gaertn. Пыльца ели представлена несколькими процентами и только в разрезе Выру содержание ее увеличивается до 14\%. Пыльца лещины, граба и широколиственных встречается спорадически. Количество пыльцы травянистых растений в более крупнозернистых отложениях в низах разрезов и в морене меньше $20 \%$ и местами составляет всего лишь несколько процентов (разрез Выру). В более тонкозернистых отложениях содержание травянистых растений находится в пределах $20-30 \%$. Количество пыльцы карликовой березы значительно колеблется (см. рис. $2-5)$.

В препаратах содержание пыльцы небольшое и микроостатки растений встречаются редко. Исключение составляет местонахождение Рем- 


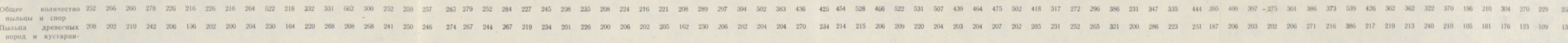

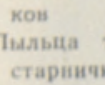

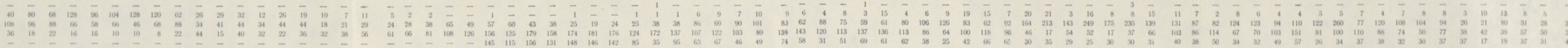

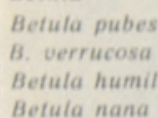

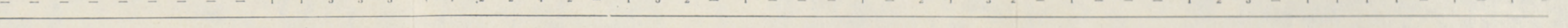



мески, где в этой части разреза обнаружены микроостатки древесины и хвоща.

В верхней части зоны попеременно преобладает пыльца березы и сосны, но в общем господствует сосна. На диаграмме Реммески сосна преобладает на протяжении всего рассматриваемого отрезка разреза. Участие пыльцы ольхи вверх по разрезу уменьшается, хотя ее содержание остается более или менее постоянным. Пыльца ели встречается в небольших количествах. Содержание пыльцы травянистых растений повышается до $30-40 \%$ и карликовой березы - до $40-50 \%$. Их кривая при этом имеет более постоянный характер, чем в нижней части XII зоньі.

Содержание пыльцы в препаратах несколько увеличивается. В них найдены также растительные микроостатки зеленых мхов и древесины.

Среди травянистых растений в XII зоне преобладает пыльца полыней, много пыльцы маревых, осоковых и злаковых. Только в разрезе Реммески преобладает пыльца осоковых.

Присутствует пыльца ксерофитов и мезоксерофитов: Ephedra sp., Eurotia ceratoides (L.) C.M. A., Artemisia типа Seriphidium, Hippophae rhamnoides L., а также Chenopodium album L. и Chenopodium rubrum L. Пыльца Hippophae rhamnoides L., кроме одного зерна в разрезе Выру, обнаружена начиная с верхней части XII зоны. Наличие пыльцы Нірроphae rhamnoides L. в разрезах начиная со второй половины XII фазы отмечено также в работах Иверсена (Iversen, 1954) и Кабайлене (1965). Другие тундровые растения, кроме карликовой березы, представлены пыльцой Dryas octopetala L. и спорами Lycopodium pungens La Pyl., Lycopodium apressum (Desv.) Petr. и Selaginella selaginoides (L.) Link.

Видовое разнообразие травянистых растений в верхней части XII зоны более значительное, чем в нижней.

Наличие пыльцы термофильных древесных пород вместе с пыльцой тундровых растений и представителей пионеров растительности, а также другие ранее названные признаки заставляют считать пыльцу Alnus glutinosa (L.) J. Gaertn., Carpinus betulus L., Corylus avellana L. и широколиственных (Ulmus sp., Tilia sp.) переотложенной. Если это так, то переотложена и часть, возможно даже бо́льшая часть, пыльцы умеренно термофильных древесных пород (Pinus sylvestris L., Picea exelsa (Lam.) Sink., Betula pubescens Ehrh., Alnus incana (L.) Moench, Betula humilis Schrank. Пыльца травянистых растений, вероятно, переотложена в меньшей мере, так как в морене этой пыльцы мало, а кверху содержание ее быстро увеличивается. Не переотложена, видимо, и пыльца Betula nana L. Следовательно, в нижней части XII зоны доминирует переотложенная пыльца, а пыльца местной растительности представлена главным образом видами тундровых растений и ксерофитами. Спектры нижней, XII зоны на диаграммах, видимо, не отражают состава окружающей растительности и поэтому соответствующие отложения нельзя рассматривать как биостратиграфическую подзону XII зоны. Следовательно, от . ложения стдельных местонахождений, рассматриваемые в качестве нижней части XII зоны, вряд ли являются одновозрастными. При этом следует иметь в виду, что главным источником переотложенной пыльцы служит морена, а в верхней морене разных местонахождений пыльцевой состав древесных пород довольно сходный. Кроме переотложения пыльцы из морены, загрязнение происходило и заносом пыльцы ветром из отдаленных районов с более развитой растительностью.

На основе уменьшения количества пыльцы ольхи и других термофильных древесных пород, изменения состава остальных древесных пород, повышения кривых травянистых растений и карликовой березы

6 ENSV TA Toimetised $\mathrm{K}+\mathrm{G}-269$ 
можно предполагать, что в верхней части XII зоны переотложение пыльцы и спор было менее значительным и спорово-пыльцевые спектры более полно отражают местную растительность тундрового типа совместно с представителями ксерофитов.

Следующую, XI зону (аллерёд) в Южной Әстонии можно расчленить на две части $(a$ и $b)$. Нижняя из них $(b)$ характеризуется постоянным падением кривой травянистых растений и карликовой березы и подъемом кривой древесных пород и древовидных берез. Среди древесных пород доминирует (Реммески) или присутствует в довольно значительном количестве (Выру, Визузи) пыльца березы.

В верхней части (a) XI зоны кривые травянистых растений и карликовой березы падают еще ниже. Их содержание снижается соответственно до 3-4 и 4-6\%. Пыльца сосны достигает максимума (80-90\%). В ХІ зоне пыльца ольхи $(1-2 \%)$ встречается спорадически.

Хотя доля пыльцы травянистых растений в XI зоне значительно меньше, чем в XII, соотношения количеств пыльцы полыней, осоковых, злаковых и маревых и здесь остаются близкими. Лишь во время климатического оптимума XI зоны, совпадающего с максимумом сосны, отмечается уменьшение количества пыльцы полыней и увеличение пыльцы осоковых.

Пыльца перигляциальной растительности встречается, но реже, чем в низах отложений. Пыльца Hippophae rhamnoides L. на диаграммах Выру и Реммески присутствует постоянно (см. рис. 2 и 3). Среди спор тундровых растений встречены споры Selaginella selaginoides (L.) Sink. и Lycopodium pungens La Pyl. (очень редко). При этом пыльца водных растений встречается чаще и представлена термофильными и умеренно термофильными видами: Myriophyllum verticillatum L., Sparganium sp., Sagittaria sp. и др. Среди травянистых растений найдена еще пыльца разных видов болотных и луговых растений: Epilobium sp., Plantago maritima L., Plantago media L., Polygonum hydropiper L., Polygonum persicaria L., Valeriana officinalis L., Filipendula ulmaria (L.) Мах. Видовой состав травянистых растений в XI зоне в общем более разнообразен, чем в XII зоне.

На диаграммах Визузи и, частично, Выру перед климатическим оптимумом XI зоны количество пыльцы травянистых растений и карликовой березы несколько увеличивается. В настоящее время еще рано говорить о том, связано ли это с кратковременным похолоданием в середине XI зоны, или мы имеем дело со случайными локальными изменениями растительности.

Содержание пыльцы в препаратах обильное и сохранность ее в XI зоне хорошая. Найдены микроостатки болотных растений, древесины и зеленых мхов.

Судя по спорово-пыльцевым спектрам, нижняя граница аллерёда переходная, а верхняя резкая и отчетливая.

В залегающих выше отложениях X зоны (верхний дриас) кривые травянистых растений и карликовой березы поднимаются и достигают на диаграммах Выру 30-40 и 36\%, Реммески 40 и 20-30\%, Сойтсъярв 56 и $50-60 \%$, Визузи $40-50$ и $30-40 \%$ и Пяйдре $59-60$ и $40-55 \%$. Среди древесных пород пыльца березы обычно несколько преобладает над пыльцой сосны. В верхней части зоны наблюдается, хотя и кратковременный, подъем пыльцы сосны перед окончательным преобладанием березы в пребореальном периоде. Количество пыльцы ели начиная с верхней части аллерёда несколько увеличивается и достигает в нижней части X зоны на диаграммах Выру и Визузи $10-12 \%$, Реммески $14 \%$, Пяйдре и Сойтсъярв $6-7 \%$. В верхней части Х зоны однов)е- 
менно с падением кривой травянистых растений в некоторых местонахождениях (Пяйдре, Выру, Реммески) намечается новый подъем кривой ели. Особенно своеобразна диаграмма Реммески, часть которой, соответствующая переходу к пребореальному периоду, вытянута. Количество пыльцы ели здесь достигает $23 \%$.

Так как в Северной Эстонии в XI зоне найдены макроостатки ели (Thomson, 1935), а спорово-пыльцевой состав аллерёдских отложений Южной Эстонии близок к составу растительности лесного или лесотундрового типа, то можно полагать, что бо́льшая часть пыльцы ольхи и ели в этих осадках не переотложена.

Выше X зоны происходит значительный перелом в соотношениях количеств пыльцы основных групп растительности, отдельных древесных пород и травянистых растений. Қоличество пыльцы травянистых растений уменьшается. Поднимается кривая пыльцы злаковых, а также осоковых, а кривые пыльцы полыней и маревых падают. Пыльца перигляциальной растительности и пыльца и споры тундровых растений встречаются только в нижней части IX зоны и то лишь в отдельных случаях. Выше они уже не представлены. Среди пыльцы водных растений встречены термофильные и умеренно термофильные виды: Typha latifolia L., Myriophyllum verticillatum L., Sparganium sp., Sagittaria sp.

В нижней части IX зоны пыльцы карликовой березы 5-10\%, в верXней $1-2 \%$. Среди древесных пород в изученных разрезах кульминирует пыльца березы.

Соответственно тематике статьи в ней не рассматриваются вышележащие голоценовые отложения.

На основании изученных спорово-пыльцевым методом разрезов можно установить следующие общие закономерности в спорово-пыльцевых диаграммах нозднеледніковых отложений Южной Эстонии. Изменения в содержании пыльцы основных групп растений и различных древесных пород, а также растений тундровой группы ксерофитов и мезоксерофитов в указанных разрезах происходят довольно закономерно и позволяют с достаточной достоверностью расчленить позднеледниковые отложения Южной Эстонии на три зоны (XII, XI, X).

Палинологические границы зон в изученных разрезах отмечаются изменениями в литологическом характере отложений. Это же явление наблюдается и в соответствующих местонахождениях Северной Эстонии (Пиррус, Раукас, 1969).

Отложения XII зоны представлены ленточными глинами или ритмично-слоистыми алевритистыми и глинистыми отложениями. В нижней части зоны на морене иногда залегают более крупнозернистые отложения. В верхней части ритмичность отложений неотчетливая или совсем отсутствует. Растительные остатки обнаруживаются чаще в низах верхней части XII зоны. В XI зоне отложения представлены глинами, алевритистыми глинами и алевритами с черными прослойками разложившейся органики. В Х зоне обычно встречаются алевриты с прослойками песка и остатками гипновых мхов. В голоцене начиная с IX зоны отложения представлены сапропелями и озерной известыо. Выше по разрезу залегают болотные отложения.

Как известно, в более южных районах Прибалтики и Западной Европы, освободившихся ото льда раньше территории Южной Эстонии, в XII зоне выделяются три подзоны. Какую часть XII зоны охватывают соответствующие отложения Южной Эстонии, в настоящее время уверенно сказать нельзя. Все рассматриваемые разрезы расположены южнее краевых образований пандивереской (невской) стадии: разрез Реммески - в пределах краевых образований хааньяской (лужской) стадии, 
разрез Выру - несколько севернее их и остальные разрезы - между предельными краевыми образованиями пандивереской и хааньяской стадий (фаз).

По Л. Серебрянному и А. Раукасу $(1966,1967)$, убывание ледника с хааньяских краевых образований началось в бёллинге, а пандивереские краевые образования сформировались в среднем дриасе. Пока имеется только одна датировка подморенных отложений бёллингского возраста по $\mathrm{C}^{14}: 12650 \pm 500$ лет назад (ТА-57) (Лийва и др.; 1966; разрез Куренурме недалеко от местонахождения Выру). Поскольку эта датировка единственная, то ее все же нельзя считать окончательной.

Опираясь на изложенное и датировку абсолютного возраста, можно предположить, что образование изученных нами позднеледниковых отложений началось в бёллинге. Имеющнйся палинологический материал не подтверждает этого, так как спорово-пыльцевой состав не указывает на потепление климата раньше аллерёда. Возможно, однако, что нижние отложения XII зоны все же образовались во время бёллингского потепления, но из-за близкого расположения местонахождений к леднику развитие местной растительности задержалось. Можно сделать и другое предположение, которое из-за рассмотренных выше причин кажется менее вероятным. Если считать, что большая часть пыльцы умеренно термофильных древесных пород, особенно Betula pubescens, все же не переотложена, то в нижней части XII зоны спорово-пыльцевой состав лесотундрового типа должен быть близким к составу пыльцы и спор позднеледниковых отложений Литвы, условно рассматриваемых как отложения бёллингского возраста (Кабайлене, 1965).

Следовательно, абсолютное время начала накопления отложений XII зоны в Южной Эстонии остается еще не выясненным, и этот вопрос нуждается в дальнейших исследованиях. Переотложение пыльцы и спор затрудняет интерпретацию спорово-пыльцевых диаграмм XII зоны, но на основе более обширного материала, очевидно, можно будет получить более достоверные результаты.

\section{Л И ТЕРАТ У РА}

$\mathrm{K}$ a 6 а й лен е M. 1965. Некоторые вопросы стратиграфии и палеогеографии голоцена Юго-Восточной Литвы. Стратиграфия четвертичных отложений и палеогеография антропогена Юго-Восточной Литвы (Тр., вып. 2). Вильнюс.

Л и й в а А. и др. 1966. Список радиоуглеродных датировок Института зоологии и ботаники Академии наук Эстонской ССР. Изв. АН ЭССР, Сер. биол., 15, № 1.

Мянниль Р. П., Пир у у Р Р. О. 1963. Разрезы позднеледниковых отложений у Хальяла и Выру. Тр. Ин-та геол. АН ЭССР, ХІІ. Таллин.

О р в и к у К. К. 1960. Четвертичная система. В кн.: Геология СССР, т. XXVIII. М.

П и р рус Р. О., Р аука с А. В. 1969. О характере и времени освобождения территории Эстонии от ледников последнего оледенения. Tр. по четв. системе, IV Рига (в печати).

С еребряннныи Л. Р., Р а ук а с А. В, 1966. Трансбалтийские корреляции краевых ледниковых образований позднего плейстоцена. В кн.: Верхний плейстоцен. Стратиграфия и абсолютная геохронология.

С еребрянный Л. Р., Р а ука с А. В. 1967. Сопоставление готигляциальных краевых ледниковых образований во впадине Балтийского моря и прилегающих к ней странах. Baltica, 3. Вильнюс.

Iversen J. 1954. The Late-Glacial flora of Denmark and its relations to climate and soil. Danmarks Geologiske Undersøgelse, II, Raekke, No. 80. København. 
$\mathrm{Ni}$ Is s o n T. 1935. Die pollenanalytische Zonengliederung der spät- und postglazialen Bildungen Schones. Geol. Fören. Förhandl., Bd. 57, H. 3. Stockholm.

O rviku K. 1961. Antropogeeni (kvaternaari) stratigraafia ja paleogeograafia küsimusi Eestis. Geoloogiline kogumik. Tartu.

Thoms on P. 1935. Vorläufige Mitteilung über die spätglaziale Waldgeschichte Estlands. Geol. Fören, Förhandl., Bd. 57, H. 3. Stockholm.

Институт геологии

Академии наук Эстонской ССР
Поступила в редакцию $22 /$ XI 1968

\section{REET PIRRUS.}

\section{LOUNA-EESTI HILISGLATSIAALSETE SETETE STRATIGRAAFILINE LIIGESTAMINE OIETOLMUANALUUSI ABIL}

Lõuna-Eesti hilisglatsiaalșete setete leiukohtade (Vōru, Remmeski, Visusi, Soitsjärv, Päidre) palünoloogilise uurimise alusel esitatakse ōietolmukihtide iseloomustus, setete stratigraafiline liigestus ning selle seos mandrijää taandumisega.

Leiukohtade ōietolmudiagrammid leiduvad joonistel $2-6$, õietolmuanalüüsi tulemused - tabelis 1 .

Stratigraafilise liigestamise peamiseks aluseks on mutused 1) puude ja rohttaimede õietolmu hulgalises vahekorras, 2) vaevakase ōietolmu hulgas ja 3) männi, kase jt. puude õietolmu hulgalises vahekorras. Nende muutuste pōhjal on vōimalik liigestada Lõuna-Eesti hilisglatsiaalsed setted kolmeks öietolmukihiks (XII, XI, X). Kasutatud on T. Nilssoni indekseid (Nilsson, 1935).

Umbersettinud ôietolmu rohkele sisaldusele XII kihi alumises osas viitavad 1) puude (eriti kase, lepa) halvasti säilinud ōietolmu esinemine, 2) õietolmukōverate kōikuvus, 3) termofiilsete puude (rohkesti Alnus glutinosa (L.) J. Gaertn., sporaadiliselt Carpinus betulus L., Corylus avellana L. ja laialehelised) öietolmu esinemine koos tundrataimede ning kserofüütsete ja mesokserofüütsete pioneertaimede ñietolmuga, 4) XII kihi alumise osa öietolmukoostise sarnasus nende all lasuva moreeni ōietolmu koostisega. Olespoole ümbersettinud õietolmu osatähtsus tōenäoliselt väheneb ning XI ja X kihis on see juba tühine. Ilmselt on ümber settinud termofiilsete puude õietolm. Kui suur osa aga mõôdukalt termofiilsete puude õietolmust ümber on settinud, on raskem öelda. Küllalt tõenäoline on, et XII kihi alumise osa kihitatud liivakate setete ja viirsavide settimise ajal valitsesid ümbruskonna taimestikus tundrataimed ja kserofüüdid ning esitatud ōietolmuspektrid ei kajasta ümbruskonna taimestikku ōigesti.

Remmeski leiukoht asub haanja (luuga) staadiumi (faasi) servamoodustiste alal, Vōru leiukoht sellest veidi pōhjapool ning ülejäänud leiukohad haanja ja pandivere (neeva) staadiumi äärmiste servamoodustiste vahelisel alal. L. Serebrjannôi ning A. Raukase (Серебрянный, Раукас, 1966) järgi toimus mandrijää taandumine haanja staadiumi servamoodustistelt böllingis ning pandivere staadiumi servamoodustiste kujunemine vanemas drüüases.

Seega peaks hilisglatsiaalsete setete kujunemine Lōuna-Eestis algama böllingis. Oietolmudiagrammid ei peegelda kliima soojenemist enne XI kihi kujunemist. Küsimust, millal algas hilisglatsiaalsete setete kujunemine Lōuna-Eestis, on olemasoleva materjali pōhjal raske lōplikult otsustada, kuna hilisglatsiaalsete setete alumises osas ōietolmu ümbersettimine sel või teisel määral on ilmne.

Kokku vōttes vōib öelda, et hilisglatsiaalsed setted Lõuna-Eestis hakkasid kujunema mitte hiljem kui vanemas drüüases.

Palünoloogiliste piiridega kaasnevad muutused setete litoloogilises koostises.

\section{REET PIRRUS}

\section{STRATIGRAPHIC DIVISION OF SOUTH ESTONIAN LATE GLACIAL DEPOSITS BY MEANS OF POLLEN ANALYSIS}

On the basis of a palynological study of the South Estonian sites of Late Glacial deposits (Vōru, Remmeski, Visusi, Soitsjärv, Päidre), the author presents the characteristics of the pollen zones as well as a stratigraphic division of the deposits, and elucidates the connection of the latter with the retreat of the continental ice.

The pollen diagrams are to be found in Figs $2-6$, and the results of the pollen analysis - in Table 1 . 
The stratigraphic division is mainly based on the changes 1) in the quantitative proportion of tree and herb pollen, 2) in the amount of dwarf birch pollen, 3) in the quantitative proportion of the pollen of pine, birch, and other trees. According to those changes, it is possible to differentiate three pollen zones (XII, XI, X) in the South Estonian Late Glacial deposits. The author has used the indexes of T. Nilsson (Nilsson, 1935).

The large content of rebedded pollen in the lower part of zone XII is indicated by 1) a bad state of preservation of the tree pollen (birch and alder, in particular), 2) a fluctuation of the pollen curves, 3 ) the simultaneous occurrence of the pollen of thermophilic trees with the pollen of tundra plants and that of xerophytic and mesoxerophytic pioneer plants, 4) a similarity in the content of the pollen of the lower part of zone XII with that of the underlying till. The proportion of the pollen that has rebedded upwards evidently decreases, and in the deposits of zones XI and X it is already negligible. The pollen of the thermophilic trees has been obviously rebedded, but it is more difficult to assert the share of the rebedded pollen of temporately thermophilic trees. It is quite probable that during the sedimentation of laminated sandy deposits and varved clays in the lower part of zone XII, tundra plants and xerophytes prevailed in the surrounding flora, and the pollen spectra presented do not reflect the flora of the surroundings with a sufficient accuracy.

The deposit on the site of Remmeski is situated in the area of the edge formation of the Haanja (Lıga) Stage, the Vōru deposit _ , somewhat farther north, and the remaining ones - in the intermediate area between the extreme ice marginal formations of the Haanja (Luga) and Pandivere (Neva) Stages. According to L. Serebryanny and A. Raukas (Серебрянный, Раукас, 1966), the retreat of the ice sheet from the edge formations of the Haanja phase occurred in the Bölling, and the edge formations of the Pandivere phase were formed in the Older Dryas.

Thus, the formation of the Late Glacial deposits of South Estonia must have begun in the Bölling. The pollen diagrams do not reflect any amelioration of the climate before the formation of the deposits of zone XI. On the basis of the material available, it is rather difficult to determine the beginning of the formation of the Late Glacial deposits in South Estonia, since a rebedding, to one extent or another of the pollen in the lower part of zone XII is quite obvious.

In conclusion, one may assert that the Late Glacial deposits of South Estonia began to be formed not later than in the Older Dryas.

The palyno'ogical boundaries were accompanied by changes in the litho'ogical composition of the deposits. 